\title{
Changing Pathology with Changing Drugs: Skin Cancer
}

\author{
M.B. Karpova M.J. Barysch M.C. Zipser N. Schönewolf L.E. French \\ R. Dummer
}

Department of Dermatology, University Hospital of Zürich, Zürich, Switzerland

\section{Key Words}

Basal cell carcinoma - Melanoma - Squamous cell

carcinoma - Molecular abnormalities - Targeted therapy •

Skin cancer

\begin{abstract}
Today skin cancer is mainly treated by surgical interventions. New findings concerning molecular biology and the signaling pathways in epithelial skin cancers such as basal cell carcinoma, squamous cell carcinoma or melanoma, and mesenchymal skin cancers such as angiosarcoma and dermatofibrosarcoma protuberans (DFSP) have identified new molecular targets for a systemic or local treatment approach. For DFSP there is an opportunity already today to reduce the intensity of surgical procedures by pretreatment with targeted therapy. This article highlights important aspects in several skin cancer types.

Copyright $\odot 2011$ S. Karger AG, Basel
\end{abstract}

\section{Introduction}

Skin cancer is more common than all other cancer forms in human beings. Virtually every single cell type in the skin can transform and start uncontrolled proliferation. In the last decades, intensive research in the field of molecular biology has identified several key events that contribute to the molecular pathogenesis of skin cancers including basal cell carcinomas (BCCs), squamous cell carcinomas (SCCs), and others. Interestingly, there are a number of new therapeutic strategies that are able to specifically target the affected pathways.

\section{Smoothened-Targeted Therapy in BCC}

Molecular Biology of BCC

$\mathrm{BCC}$ is one of the most common neoplasms in the Caucasian population. Molecular events that are seen in these tumors are rather monotypic in comparison to other malignancies, with translocations and inversions involving $9 \mathrm{q}$ being a common aberration in BCCs [1-3]. BCCs rarely develop metastases and are considered to be genetically stable. The high level of stability associated with BCC has been confirmed using comparative genomic hybridization [4] and loss of heterozygosity [5] analyses which showed a reoccurrence of loss on $9 q$ (in 30-60\% of tumors), further refining this region as 9q22. Other aberrant loci present in more then $10 \%$ of the cases and detected in these and similar studies using molecular-based cytogenetic approaches included chromosome arms 1q, $6 \mathrm{p}, 6 \mathrm{q}, 9 \mathrm{p}, 17 \mathrm{p}, 17 \mathrm{q}$, and chromosome X [4, 6-9].

Dr. nat. sci. Maria B. Karpova

Department of Dermatology, University Hospital of Zürich

Gloriastrasse 31

CH-8091 Zürich (Switzerland)

Tel. +41 4425539 78, E-Mail maria.karpova@usz.ch 
The majority of BCCs are sporadic, but there is a congenital syndrome, i.e. basal cell nevus syndrome (BCNS), which promotes tumor onset. The main promotion of the development of BCCs is provided by sun exposure; however, this relation is complex. Extensive work was done to find predisposing epidemiological factors to explain this tight relation between the environment and BCC development. Among the contributing polymorphic alleles known to date one can name cytochrome P-450 (CYP2D6 EM genotype), glutathione S-transferase-null genotypes (GSTT1 and GSTM1), GSTM3, vitamin $\mathrm{D}$ receptor, and tumor necrosis factor gene polymorphisms [10-18]. Very recent association studies of Eastern European and Icelandic cohorts of BCC patients detected fair skin haplotypes of ASIP and TYR loci to increase the risk of BCC development as well as single nucleotide polymorphism variants on 1p36 and 1q42 loci. These new discoveries can point to new targets for BCC chemotherapy $[19,20]$.

Somatic mutations were found in several genes involved in the Hedgehog $(\mathrm{HH})$ signaling pathway. The first described were mutations in patients with BCNS found in the patched homologue 1 (PTCH1) gene located on chromosome 9q22 [21-24]. BCNS was described by Robert Gorlin in the middle of the last century and is often presented as the development of multiple (tens to hundreds) BCCs in an affected patient and at a young age [25]. Patients with BCNS also have a higher risk of developing other types of malignancies, especially medulloblastomas (MB) and radiotherapy-induced BCCs [6-8]. PTCH1 is a human homolog of the patched (ptc) gene in Drosophila melanogaster and functions as an inhibitor of the $\mathrm{HH}$ signaling pathway. Mutations in this gene lead to constant upregulation of the pathway which is crucial in the development of all BCCs $[26,27]$. PTCH1 is not the only gene in the mutation spectrum of BCC which includes genes that regulate skin color, members of the phosphoinositide 3-kinase (PI3K)-Akt and the Wnt pathways, FOXM1 and DNA damage repair genes, and TP53 [28-30]. Furthermore, about $10 \%$ of tumors carry mutations in the gene smoothened (SMO), another important member of the $\mathrm{HH}$ pathway encoding a regulator downstream of PTCH1 [31-34].

Definition of the above-mentioned events in the molecular pathogenesis of BCC has led to the well-accepted conclusion that upregulation of the $\mathrm{HH}$ signaling pathway is essential to promote BCC initiation. Therefore, this signaling pathway has been chosen as a privileged target for the development of molecular interventions.

\section{HH Pathway}

Elucidation of molecular aberrations in BCCs enabled the subsequent characterization of a group of human cancers where disturbances of the $\mathrm{HH}$ signaling pathway govern tumor development.

In brief, a family of extracellular ligands with 3 members, i.e. Sonic Hedgehog (SHH), Desert Hedgehog $(\mathrm{DHH})$, and Indian Hedgehog $(\mathrm{IHH})$, initiates the $\mathrm{HH}$ signaling cascade. All 3 protein ligands are able to bind Patched 1 (PTCH1), a 12-pass transmembrane receptor protein which releases its repression of the pathway activity upon binding of a ligand. PTCH1 suppresses the $\mathrm{HH}$ signaling pathway through the inhibition of the G protein-coupled receptor-like protein Smoothened (Smo), which serves as a pathway activator. Through a range of protein interactions Smo transmits a signal to the genes amplified in glioblastoma (Gli) family of transcription factors. When the signal reaches the Gli transcription factors, Gli1, Gli2, and/or Gli3, changes in transcription can then lead to cell proliferation and differentiation [35, 36]. Interestingly, stem cells express a lot of genes that are transcriptionally regulated by Gli 1,2, and/or 3, thus providing a link between the $\mathrm{HH}$ signaling pathway and stem cell function. A short list of target genes involves Gli1, PTCH1, D-type cyclins, BMI1, and Bcl2. Included amongst the transcriptional targets of $\mathrm{HH}$ signaling in BCCs are the pathway's own members: PTCH1, forming a negative feedback that dampens the pathway; GLI1, providing a positive feedback for the pathway, and HHIP, which encodes an $\mathrm{HH}$-binding protein $[37,38]$.

The $\mathrm{HH}$ pathway activity is important for the development and homeostasis of several organs and tissues [39]. The physiological mechanism of $\mathrm{HH}$ signaling is paracrine; however, during carcinogenesis it is suggested that an autocrine mechanism may be involved [40]. The development of several tumor types is stimulated by mutations in PTCH1 or downstream Smo proteins. Thus, germ line mutations in PTCH1, within manifestations of $\mathrm{BCNS}$, lead to the development of medulloblastoma, ovarian cysts, and ovarian carcinoma. In terms of incidence, mutations in Ptch and/or Smo genes leading to activation of the $\mathrm{HH}$ pathway are found in more than $70 \%$ of sporadic BCC $[32,41]$ and in $20-30 \%$ of MB $[42$, 43].

\section{Smoothened-Targeted Compounds}

Elaboration of small molecule antagonists of Smo was encouraged by the elucidated and clear molecular pathway of tumor development in BCCs. Since the most prevalent mutations in BCC are activating mutations in 
PTCH1 and SMO genes, $\mathrm{HH}$ signaling becomes ligand independent in these tumors. Thus, blockade of ligand binding will not result in a therapeutic effect, and inhibition must be targeted to Smo and downstream signaling molecules.

The first Smo-targeted inhibitors, i.e. cyclopamine and jervine, were isolated from corn lilies (Veratrum californicum) as teratogenic and antitumor agents [44-46]. However, the chemical structure of these plant alkaloids resulted in low-affinity binding to the Smo protein and decreased bioavailability. This fostered the development of new potent synthetic modifications such as HhAntag [47], SANT1-SANT4 [46, 48], Cur-61414 [49], GDC-0449 [50], and very recently IPI-926 [51]. Several of these inhibitors were able to prevent in vivo tumor progression in MB models driven by mutations in Ptch [52, 53]. GDC0449 is a new-generation, orally administrated, synthetic Smo inhibitor possessing higher potency and specificity. In a recent phase I trial, systemic administration of GDC0449 showed promising tumor regressions in metastatic or locally advanced BCC [54]. With respect to clinical testing, very few Smo inhibitors have been used to date in humans. The pioneer is cyclopamine, which is reported to induce the regression of sporadic human BCCs after topical application and inhibit the xenograft growth of $\mathrm{HH}$-overexpressing tumors [40, 55-59]. Another molecule tested topically in humans is Cur-61414, but this promising synthetic Smo agonist did not penetrate human skin well (http://www.curis.com/news.php). The problem of skin penetration is a recurrent obstacle for topical drug application. Presently several strategies are being pursued in order to overcome this issue. One of the actively explored possibilities for cancer therapy is the use of nanoparticles to deliver drugs under the stratum corneum. Some advances have been made recently with the development of solid lipid nanoparticles and core-multishell nanoparticles which can penetrate the skin with high efficiency [60-62]. More promising results, as has already been mentioned, have been obtained using systemically administrated GDC-0449. This molecule, as well as IPI-926, is now entering further clinical trials, is well tolerated, and has very limited acute and chronic toxicity [63].

The current active development of therapeutic agents targeting Smo opens several promising therapeutic avenues. Most promising for the treatment of restricted areas is topical application, as has been shown for cyclopamine, thus avoiding systemic exposure. Points for consideration in this respect are: (1) the long-term complete clearance rate, (2) the types of BCCs responding to treatment

Changing Pathology with Changing

Drugs: Skin Cancer (superficial BCC vs. nodular BCC vs. aggressive infiltrative BCC), (3) the time period required to reach tumor clearance, and (4) local side effects and the cosmetic outcome. Patients with a genetically determined high incidence of BCC, e.g. xeroderma pigmentosum or BCNS patients, can profit from systemic therapy. New molecules might be investigated in these patient populations as monotherapeutic tools and in the context of chemoprevention. If successful, such new Smo-targeting drugs could then be investigated in patients with multiple sporadic BCCs. Mounting evidence from mouse models of BCC, as well as early experiences with local and systemic utilization of SMO antagonists, indicates that molecular interventions inhibiting the $\mathrm{HH}$ signaling pathway are promising approaches for the treatment of BCC. It is also important to note that there is no evidence that mutation screening is needed before enrolling patients for such a treatment because the vast majority of mutations found in BCCs are mutations leading to $\mathrm{HH}$ pathway activation in a ligand-independent manner. These include inactivating PTCH1 mutations leading to the lack of pathway repression (approximately $90 \%$ of mutations) and activating SMO mutations leading to constant further signaling ( $\sim 10 \%$ of mutations); mutations in the $\mathrm{HH}$ ligand itself are also described [33, 34, 63-66]. However, mutations occurring during treatment may be a concern. As it has been reported for MB, GDC-0449 appears to be able to induce tumor mutagenesis leading to chemoresistance. Therefore, combination therapy will be investigated with agents interfering with molecules downstream of the $\mathrm{HH}$ pathway, such as TGF- $\beta$, MAPK, or PI3K inhibitors [6770].

The great need for well-tolerated local and systemic treatment options in patients with multiple BCCs is explained by the continuously increasing incidence of these tumors. It is still unclear which mode of administration, systemic or local, will yield the best efficacy-to-risk ratio. This parameter will determine the place for Smo-targeted therapy in a competitive environment of BCC treatment options alongside surgical procedures, physical therapy (irradiation or photodynamic therapy), and topical immune modulation.

\section{Currently Used Drug Therapy for BCC}

There are currently several options available for the treatment of BCCs, e.g. 5-fluorouracil (5-FU), a pyrimidine-like inhibitor of thymidylate synthase which prevents DNA synthesis in tumor cells. The exact mechanism of action in BCC remains unclear for this drug, but it has been suggested that 5 -FU downregulates $\mathrm{HH}$ path- 
way target molecules at both the messenger RNA and protein levels. Interestingly, upregulation of the Gli1 transcription factor restores cell viability and migration inhibited by 5 -FU [71].

Based on our improved understanding of the molecular genetics of BCCs, retinoids, especially tazarotene (Tazorac; Allergan), are promising tools for prevention or therapy. Tazarotene has been shown to decrease Glil expression and upregulate CRABPII, a target gene of retinoid signaling. Retinoids act through the transcription factors RAR and RXR initiating cellular differentiation and apoptosis as well as extracellular matrix synthesis. They are widely used to treat inflammatory (such as psoriasis or chronic eczema) or neoplastic diseases including acute promyelocytic leukemia, cutaneous T-cell lymphomas, and non-melanoma skin cancers. In Ptch1+/- mice a controlled chemoprevention trial demonstrated that the topical use of tazarotene inhibits the formation of BCCs induced with either UV or ionizing radiation [72, 73]. The total complete clearance rate for BCCs was, however, only $30.5 \%$; therefore, topical tazarotene is not a reliable therapeutic option. In contrast, the substance might be useful as a chemopreventive topical approach based on the data derived from animal models. Prospective trials in humans are testing this hypothesis.

A potent therapeutic agent for the treatment of selected BCCs is imiquimod, a low-molecular-weight synthetic immunomodulator which can induce up to $87 \%$ of the clinical and histologically verified clearance of superficial BCCs. One of the major antitumor actions of imiquimod is the induction of inflammation resulting in an IFN- $\alpha$ driven immune response which has also been confirmed in a mouse model of melanoma [74]. Molecularly this is achieved through triggering of the Toll-like receptor $7 /$ MyD88/NF- $\mathrm{KB}$ pathway and the consequent induction, synthesis, and release of selected cytokines, including IFN- $\alpha$ by plasmacytoid dendritic cells. This ability of imiquimod mimics a well-documented treatment of BCC with repeated intratumoral injections of IFN- $\alpha$ [75]. Simultaneously, imiquimod promotes the migration and activation skin Langerhans cells to the regional lymph nodes, Bcl-2-dependant apoptosis of tumor cells and suppresses feedback mechanisms limiting inflammatory responses [76]. How much these pathways contribute to tumor repression in vivo is still undefined $[77,78]$. Another interesting phenomenon is the preferential upregulation of Jagged1 protein after treatment with imiquimod. Jagged1 plays an important role in the differentiation of keratinocytes as activation of the Notch pathway triggers terminal keratinocytes differentiation [79].

\section{Epidermal Growth Factor Receptor-Targeted Therapy in SCC}

SCC is another very common type of cutaneous malignancy and the second most common cancer in the European population. The increase in its incidence, along with the incidence of BCC, is also attributed to the extent of UV irradiation acquired during a personal lifespan $[80,81]$. Quite often advanced-stage SCCs occur in elderly patients and the use of systemic chemotherapeutic agents in such cases represents a certain clinical problem. Therefore, the development of safe and specific molecular-targeted therapies is also of great importance here. A good candidate for such development is epidermal growth factor receptor (EGFR), which is considered to be widely expressed on the surface of SCC cells. Immunohistochemical evaluations of EGFR expression revealed positivity for $40-100 \%$ of SCC tumor samples [82-84]. Since phosphorylation of EGFR is associated with the activation of downstream signaling, evaluation of the phosphorylated form of EGFR was performed by Fogarty et al. [85] and the rate was $25 \%$.

EGFR is an important regulator of tumor progression and proliferation in several types of cancer. Preclinical and clinical tests are now focused on 2 types of EGFRinhibiting strategies: (1) anti-EGFR monoclonal antibodies that block its interaction with endogenous ligands (e.g. EGF and TGF- $\alpha$ ) and (2) small-molecule tyrosine kinase inhibitors that inactivate EGFR. Using either approach enables the discontinuation of signal transduction downstream of the EGFR and results in the arrest of tumor proliferation and spread [86-88]. Several drugs, which are products of both development strategies, have been clinically tested in recent years. Examples are: cetuximab, panitumumab, erlotinib, and gefitinib. Cetuximab yielded quite promising results in a phase II multicenter study evaluating its potential as a first-line monotherapy for patients with unresectable SCC. These results were presented at the annual ASCO meeting in 2008 and showed that $77 \%$ of patients had stable disease under cetuximab therapy and $22 \%$ of patients had a partial response [89].

Despite the promising response rates among nonsmall cell lung cancer patients who carry somatic mutations in EGFR (the incidence is about $10-15 \%$ of the Caucasian population and $30-40 \%$ of the Asian patient population), medical problems persist since a large number of patients develop resistance to EGFR inhibitors [90]. In this respect, description of a signaling crossover between $\mathrm{HH}$ and EGF pathways in brain, prostate, and skin cell models opens new horizons for therapeutic strategies. 
JUN is primarily a transcription activator and its function can be regulated at different levels and depends on phosphorylation by JNK, a target of the MAPK pathway [reviewed in 91]. A suggested mechanism of HH-EGF pathway interaction is through the EGFR-mediated activation of MEK/ERK and JUN cascades and subsequent stimulation of JUN/AP-1 binding with promoters of GLI and ERF target genes, which lead to cancer transformation and invasive growth [92-96]. An interesting recent publication reported the successful use of cetuximab and the COX-2 inhibitor celecoxib in an elderly patient [81]. Such a complex interaction of various molecular pathways provides further opportunities for the development of combination therapies of SCC treatment using a complete range of known drugs, including MEK/RAF/RAS inhibitors, among others.

Somatic mutations in EGFR are reported in about $10 \%$ of non-small cell lung cancer cases. Data about the mutation rates in SCC are missing; however, knowledge of the mutation status in SCC patients may be important for response prediction, e.g. in relation to deletion in exon 19. At present, no additional molecular knowledge is needed to start anti-EGFR therapy in SCC as opposed to lung cancer [97]. Nevertheless, it should be noted that SCC histology is associated with a better response to anti-EGFR therapy in esophageal cancer [98]. A more significant issue is acquired chemoresistance to EGFR inhibitors which can occur through mutations in EGFR, KRAS, and NRAS or through MET amplification, which leads to RAF/MAPK/ ERK or PI3K/AKT pathway activations [97, 98]. This phenomenon raises a question regarding the better performance of multikinase inhibitors versus immunotherapeutic agents but, unfortunately, clinical data to be able to privilege one class over the other are lacking at present.

\section{Targeted Therapy in Melanoma}

Melanoma is a highly aggressive malignancy originating from melanocytes. Most commonly melanoma occurs on the skin, and its incidence rate is constantly increasing worldwide. Presently, it is estimated that around 20 out of 100,000 persons per year will develop a melanoma and estimated lifetime risk for this diagnosis, e.g. in Central Europe, is as high as 1:70 [99]. The majority of affected patients are between the ages of 50 and 60 years, but one fifth of patients are under the age of 40 . Active research recently revealed a number of common genetic aberrations in melanoma; these include BRAF and RAS mutations causing activation of the MEK-kinase signaling pathway as

Changing Pathology with Changing

Drugs: Skin Cancer well as deletions and amplifications in the genome [99, 100]. However, to date, the therapeutic arsenal lacks efficient treatment modalities that can prolong overall survival rates in patients with metastatic (stage IV) melano$\mathrm{ma}$, and there has been no significant change in the mortality rate associated with melanoma over the past years.

Finding effective therapeutic options to treat melanoma has been an ongoing challenge over the past several decades. Because melanocytes originate from highly motile cells, they are thought to have a high potential for enhanced survival. In vivo, melanoma cells show low levels of spontaneous apoptosis, and in vitro resistance occurs against drug-induced apoptosis [101]. Regarding therapeutic options, a distinction between melanoma subtypes according to their genetics and biological behavior must be made [102-107]. For instance, superficial spreading melanomas, which usually occur on areas of the skin that are not regularly exposed to UV light, are prone to mutations in the BRAF molecule which leads to the activation of signal transduction via RAS and MEK/MAP/ERK-kinase pathways [107]. Bastian et al. [102, 103] recently detected a distinct pattern of chromosomal aberration specific to acrolentiginous as well as mucosal melanomas, thus emphasizing the importance of distinguishing different melanoma types, especially in the context of the increasing number of investigative or registered targeted treatment options currently available. Acrolentiginous melanoma is a rare entity accounting for $2-3 \%$ of melanoma [108]; mucosal melanoma only accounts for $0.03 \%$ of all melanoma types [109]. Such genetic heterogeneity underlines the necessity of performing genetic evaluations of melanoma patients (i.e. for the presence of the BRAF or RAS mutation) in order to choose the correct chemotherapeutic and/or targeted agent for each subgroup and poses the new challenge of personalized treatment protocols.

\section{RAS/RAF Inhibitors}

BRAF mutations are present in over $60 \%$ of melanoma biopsies. About $90 \%$ of BRAF mutations in melanoma reveal a substitution of valine to glutamic acid at position 600 , the V600E mutation [110]. Another 15-30\% of melanoma samples carry mutations in NRAS, most commonly induced by a leucine-to-glutamine substitution at position 61 [111].

BRAF and NRAS mutations are mutually exclusive, and consequently $75-90 \%$ of melanomas carry activating mutations in the Ras/Raf/MEK/ERK MAPK pathway. At the end of this pathway, ERK is phosphorylated and activates transcription factors implicated in tumor develop- 
ment. Furthermore, V600E BRAF stimulates vascular endothelial growth factor (VEGF) secretion, promoting angiogenesis $[112,113]$. NRAS also activates the PI3K pathway, leading to proliferation and invasion [114]. Although mutated BRAF and NRAS are also frequently found in benign nevi, nevi lack other specific gene alterations, thus preventing malignant transformation [115118]. BRAF mutations in benign nevi are supposed to be associated with induction of senescence [119]. Thus, melanoma is a good indication for the development of drugs targeting the MAPK. Several MAPK kinase inhibitors have recently been developed and these are classified as either BRAF inhibitors or MEK inhibitors as described below.

\section{RAF Inhibitors}

The multikinase inhibitor sorafenib (Nexavar ${ }^{\circledR}$, BAY 43-9006; Bayer AG, Leverkusen, Germany) targets RAF, VEGF receptors (VEGFR) 1, 2, and 3, as well as plateletderived growth factor (PDGF)- $\alpha$ and PDGF- $\beta$, resulting in inhibition of tumor cell proliferation and angiogenesis. In mice xenografts, tumor growth is inhibited [114]; however, complete regression has not been achieved $[113,114$, 120].

Unfortunately, in patients, a recent, randomized, placebo-controlled, second-line phase III trial of sorafenib in combination with carboplatin and paclitaxel failed to prove beneficial in terms of overall or progression-free survival in patients with metastatic melanoma. However, the BRAF mutation status of the patient population in the trial was not assessed [121].

\section{More Specific BRAF Inhibitors}

More specific inhibitors of mutated BRAF are currently being investigated in clinical trials and have shown more promising results:

- SB590885 (GlaxoSmithKline, Collegeville, Pa., USA) is a selective RAF inhibitor that preferentially targets mutated BRAF rather than wild-type BRAF and CRAF, thus leading to a decreased proliferation of tumor cells. BRAF V600 E mutated cells are inhibited 100-fold more potently by SB590885 than by sorafenib [122].

- RAF-265 (Chir 265; Novartis, Basel, Switzerland) selectively inhibits BRAF, CRAF, and VEGFR 2 and leads to tumor regression in melanoma xenografts. Notably, downregulation of the MAPK pathway has only been obtained in RAS and BRAF mutated melanoma xenograft models [123]. This agent is currently under clinical investigation (http://clinicaltrials.gov/ ct $2 /$ show/NCT00304525). On the other hand, the se- lective V600E BRAF inhibitor PLX-4032 and its counterpart PLX-4720 (Plexxikon, Berkeley, Calif., USA) have already shown inhibition of tumor growth preclinically in BRAF V600E mutated cells but not in wild-type cells $[124,125]$. In a clinical phase I trial, a reduction of phosphorylated ERK was observed in 3 of 6 patients with V600E BRAF-mutated metastatic melanoma upon treatment with PLX4032 [126]. Furthermore, tumor regression was observed in 5 of 7 patients harboring the V600E BRAF mutation [127].

\section{MEK Inhibitors}

- PD0325901 (Pfizer, USA) showed responses in 3 out of 22 melanoma patients in a clinical phase I trial; notably, 2 of them had BRAF mutations and 1 had an NRAS mutation. However, phase II trials were suspended due to cases of retinal vein thrombosis $[110,128]$.

- AZD6244 (ARRY-142886; AstraZeneca, Wilmington, Del., USA), an inhibitor of MEK, induced G1-phase cell cycle arrest, decreased phosphorylated ERK, and showed high cytostatic activity in melanoma xenografts $[124,129,130]$. Despite the xenograft tumor growth was suppressed, the cells remained viable indicating that MEK inhibition alone is not sufficient to induce apoptosis. Tumor regression was achieved, however, using a combination of AZD6244 and docetaxel in melanoma xenografts [129]. A randomized phase II trial of AZD6244 compared to temozolomide reported partial responses in 6 out of 104 patients, 5 of which carried the BRAF mutation (12\%) [131]. Clinical trials restricted to patients carrying the BRAF mutation are ongoing.

- NRAS inhibitors, specifically farnesyl transferase inhibitors, i.e. tipifarnib (Zarnestra ${ }^{\circledR}$, R115777; Johnson \& Johnson Pharmaceutical Research and Development; Raritan, N.J., USA) and lonafarnib (Sarasar ${ }^{\circledR}$, SCH 66336; Schering-Plough Corp., Kenliworth, N.J., USA), showed disappointing results in clinical phase III trials when applied as a monotherapy. Consequently, clinical trials using these inhibitors in combination with chemotherapy are ongoing $[110,132]$.

At present, it is recommended that targeted therapy be combined with other therapeutic agents in the treatment of metastatic melanoma. In vitro and in vivo studies have shown that monotherapy with one targeted therapeutic agent may lead to tumor stabilization but not to regression [129]. It is assumed that this is because of resistance attained through a switch from BRAF to CRAF signaling [110]. This was demonstrated by one of the first studies of sorafenib, in which monotherapy showed disappointing 
results: response in 1 out of 61 patients [133]. However, patients benefitted from sorafenib therapy in combination with dacarbazine when compared to dacarbazine therapy alone [134].

Targeted therapy seems to be a promising therapy option for patients with metastatic melanoma but further investigation is still required.

\section{c-KIT-Targeted Therapy}

cKIT is located on chromosome 4q12 and codes for KIT, a tyrosine protein kinase receptor. It belongs to the class III tyrosine kinase receptor family [135-138]. It spans a distance of about $80 \mathrm{~kb}$, including 21 exons [139]. In KIT-expressing melanocytes, KIT controls permanent survival, proliferation, differentiation, and migration functions [140]. Interestingly, the KIT gene originates from a gene duplication of an ancestral PDGFR (PDGF)/KIT locus, followed by a chromosomal duplication during the evolutionary mechanisms involved in the establishment of new cell populations such as neural crest-derived pigmented cells [140].

\section{Why KIT?}

cKIT mutations are well known in gastrointestinal stroma tumors (GIST), chronic myeloid leukemia, germ line tumors such as testicular cancer, small cell lung cancer, and mastocytosis [141]. Several reports of positive treatment results in GIST, stable phases of chronic myeloid leukemia, and acute myeloid leukemia [142] prompted the idea to study other cancers' KIT status [143]. In GIST a high frequency of mutations in KIT was detected, leading to constitutive activation of the receptor [144]. Went et al. [145] were the first to detect activating cKIT mutations in melanoma.

As it was found that acrolentiginous and mucosal melanoma showed distinct chromosomal aberrations, several studies focused on and identified cKIT mutations in these melanoma types in particular $[102,103,105,106$, 146-150]. Targeting the KIT receptor using small-molecule inhibitors such as imatinib showed successful results in certain GIST and was thus evaluated in vitro [147-149, 151] as well as in vivo in clinical phase II studies for acrolentiginous and mucosal melanoma [105, 150, 152-156].

Just recently, NRAS mutations were reported to occur more often in mucosal melanoma than KIT, which is a striking new finding [151].

\section{Imatinib in Melanoma - Successes and Problems}

One of the first small molecules targeting KIT was the 2-phenyl-aminopyrimidine, imatinib [157-160]. It shows activity against several receptors such as bcr-abl, KIT, PDGF receptor (PDGFR)- $\alpha$ and PDGFR- $\beta$, ABL1, and ABL2 (ARG) $[157,161]$. Imatinib functions as a multikinase competitive inhibitor, competing with ATP for the binding site of the tyrosine kinase domain of the KIT receptor. Imatinib can only bind to the nucleotide binding site within the juxtamembrane domain when the DFG $\left(\mathrm{Asp}^{810}, \mathrm{Phe}^{811}, \mathrm{Gly}^{812}\right)$ motif is present $[162,163]$.

Imatinib has been tried in melanoma patients in several clinical studies. The first clinical trial was performed by Ugurel et al. [152] in 2005. Unfortunately, no subgrouping of melanoma took place, nor was the mutation status of KIT considered in a large group. In the 4 cell cultures studied, no mutations were found. Toxicity was outstandingly high in that study. These problems were also present in the study performed by Wyman et al. [154] in 2006; no distinction between melanoma subtypes and neither immunohistochemical nor mutation analysis was performed before running the study. Coincidentally, 1 patient suffered from mucosal melanoma, but no activating mutations were detected. Imatinib treatment was thus insufficient.

Of the 31 patients studied by Kim et al. [153], 1 patient suffered from acrolentiginous melanoma, showing high KIT expression. Imatinib treatment led to a complete response lasting up to 1 year. RNA sequencing revealed a deletion at codon 715 (kinase domain), a splice variant, which was not specific though. Biopsies were taken twice, i.e. before and during treatment. The 1 responding patient showed no alterations in KIT expression during treatment, while the nonresponding patients showed either a reduction, an increase, or no change in KIT expression. Staining was not predictive of therapeutic response [153].

In a clinical phase II study, Heinrich et al. [164] explored the efficacy of imatinib in the treatment of several life-threatening malignancies. Seven melanoma patients were treated, but no effect of imatinib was observed. In 2009, sunitinib showed promising effects in acral and mucosal melanoma in vitro [150].

\section{PDGFR-Targeted Therapy in DFSP}

\section{Dermatofibrosarcoma Protuberans}

Dermatofibrosarcoma protuberans (DFSP) is the most common sarcoma evolving on the skin; however, it is quite a rare disease with an incidence of less than $1 / 100,000$ per year [165]. DFSPs in most cases are localized on the body trunk (in $\sim 40-70 \%$ ) in particular at the 
presternal region and less frequently on the extremities and head and neck area [166]. Clinically DFSP presents in different forms, often as a plaque on which nodules can evolve. Besides the classical dermatofibroblastic tumor, the fibrosarcomatous variant, FS-DFSP, is seen as its progressive form with increased metastatic potential. The pigmented DFSP, or so called Bednar-tumor, is another subtype which is histologically defined by the occurrence of melanin-containing dendritic cells. Pigmented DFSP, as well as DFSP in general, was reported to be more frequent in the Afro-American population [166, 167]. Specific juvenile form of DFSP is called giant cell fibroblastoma (GCF) where chromosomal alterations are often found [168]. All variants show staining-positivity for CD34 [169] and histological evaluation is always required to make a definitive diagnosis of DFSP [170]. Magnetic resonance imaging (MRI) is helpful for estimation of the tumor's extent $[171,172]$. So far, the only staging system that exists was introduced by Ugurel et al. [173], according to the Short German Guidelines for DFSP, suggesting the following: stage I, primary tumor; stage II, including lymph node metastases, and stage III, with distant metastases.

\section{Clinical Development and Presentation}

Accretion and development of DFSP takes place over a long time, occasionally years, and diagnosis is often made when the tumor has already progressed and spread. Local infiltration is characterized by asymmetric and horizontal branches, often a few centimeters long, sometimes infiltrating subcutaneous structures such as fascia, muscles, or even bones. Clinically, DFSP can present as skin-colored, brown-to-yellowish, red-tinged, sclerodermiform, or telangiectatic skin [171]. Misdiagnosis as benign skin lesions, such as dermatofibroma and nevi, among others, is another reason for the often late diagnosis. A typical character trait includes the induration and compact consistency of lesions.

Most patients are under 40 years of age. Special risk factors are not known; however, an increased age $(>50$ years) is associated with a higher propensity for recurrence [174].

\section{Current Therapy Options}

Surgery in the early stage is currently the therapy of choice. A challenge is the safety margin (according to the literature it is between 1 and $5 \mathrm{~cm}$ ), especially in regions such as the presternal or head-neck area where healing with widespread scarring can often be observed. Immunohistochemical staining with CD34 is recommended in order to evaluate the tumor borders in the excised portion. Mohs micrographic surgery allows optimal tumor excision while minimizing the excision of healthy tissue, thus resulting in less complicated wound healing [170, $175,176]$.

DFSP is regarded as radiosensitive; thus, postoperative adjuvant radiotherapy is suggested to reduce the risk of local recurrences, especially in patients with narrow and/or positive surgical margins [177-180]. No remarkable benefits are known for conventional chemotherapy [165].

\section{New Molecular Background and Treatment Options}

Once the tumor has spread, systemic therapy is required. It has been shown that PDGFR plays a crucial role in the pathogenesis of DFSP. PDGFR is of importance for biological effects such as angiogenesis, cell proliferation, and apoptosis [181].

A translocation of $t(17 ; 22)$ takes place in over $90 \%$ of all DSFP patients [182]. The collagen type 1 alpha 1 gene (COLIA1) encoding type I collagen (chromosome 17) and PDGFR (chromosome 22) are located within chromosomal regions affected by this translocation. Fusion of these chromosomes in DFSP leads to constitutively overexpressed PDGFR, causing a continuous autocrine stimulation of tumor cell proliferation. Simultaneously, natural apoptosis is inhibited due to the permanent stimulation of the signal transduction pathway. Already in 1999 Shimizu et al. [183] found a relevant correlation between COLIA1-PDGF-b gene fusion and the inhibition of tumor growth by applying CGP57148B, a PDGF-b inhibitor, in vitro. Interestingly, Shimizu et al. [183] suggested that the COLIA1 part did not contribute to the cellular phenotype. However, the suggested fibroblastic origin of the tumor is attributed to the COLIA1 part [184]. Sjöblom et al. [185] showed STI571-induced (imanitib/Glivec ${ }^{\circledR}$ ) apoptosis of DFSP tumor cells but no antiangiogenic effects in in vitro experiments. However, the vascular morphology was reported to be altered upon STI571 treatment.

\section{Who Benefits from Targeting PDGFR?}

DFSP is the first dermatological tumor for which signal transduction therapy was approved based on a study of 25 cases of locally spread, recurrent or metastatic DFSP that responded successfully to imatinib $[152,186]$. Imatinib is a small multikinase inhibitor targeting PDGFR among other vital kinase receptors such as KIT. The first patient treated with imatinib showed impressive remission of the tumor, which had already metastasized [187]. 
McArthur and et al. [186] showed that out of 10 patients with locally advanced or metastatic disease the only one without positivity for the $t(17 ; 22)$ translocation did not respond to imatinib; it was thus concluded that the fusion protein is crucial for therapeutic benefit [164]. Interestingly, in contrast to imatinib treatment in GIST, neither high levels of receptor tyrosine kinase activation nor overexpression of the protein was required for successful small-molecule inhibition [186].

In 2005, Price et al. [188] administered imatinib to a child with DFSP, achieving successful tumor treatment. Labropoulos et al. [189] treated a patient with locally advanced recurrent fibrosarcomatous DFSP who had already developed metastases. Imatinib treatment (400 mg daily) led to a complete response [189].

\section{Effects of Imatinib}

If imatinib serves as a preoperative treatment option to reduce tumors to a reasonable size, $4-8$ weeks after the start of treatment a relevant tumor growth reduction should be seen on MRI. Tumor cells are transformed into less viable hyaline fibers and thus lose vitality $[186,190]$. The reduction of vital cells allows a smaller safety margin for the surgical treatment thereof. If no response can be detected at that time, a therapeutic failure is to be considered. Clinical studies for adjuvant imatinib treatment, especially after repeated local recurrences, are still to be performed.
The development of imatinib resistance is challenging; so far, no methods for predicting or preventing this are known [186]. To avoid resistance, other inhibitors such as sunitinib, dasatinib, and nilotinib should be evaluated in clinical trials on DFSP patients.

\section{Conclusion}

Imatinib has been shown to target PDGFR in particular, blocking tumor growth and proliferation in DFSP. The striking success of imatinib in DFSP and in cKITmutated mucosal or acrolentiginous melanoma is an example for the potential of targeted therapy in skin cancers on one side. On the other side, melanoma perfectly reflects the complexity of pathways resulting in a highly aggressive malignancy. Targeted therapy has recently also yielded antitumor effects in melanoma patients with mutations in the BRAF. Despite several new promising small molecules there are still no therapeutic strategies that reliably increase the survival of patients with advanced disease. Large therapeutic trials including genomic and transcriptional analysis shall identify the subpopulations of skin cancer patients that may profit from the molecules available today. With regard to BCC and SCC the conclusions are similar. Hopefully, intensive basic research together with translational research in the context of welldesigned clinical trials will pave the way to a successful and well-tolerated personalized medical management.

\section{References}

$>_{1}$ Jin Y, Merterns F, Persson B, Gullestad HP, Jin C, Warloe T, Salemark L, Jonsson N, Risberg B, Mandahl N, Mitelman F, Heim S: The reciprocal translocation $\mathrm{t}(9 ; 16)(\mathrm{q} 22 ; \mathrm{p} 13)$ is a primary chromosome abnormality in basal cell carcinomas. Cancer Res 1997;57:404406.

-2 Kawasaki-Oyama RS, Andre FS, Caldeira LF, Castilho WH, Gasques JA, Bozola AR, Thome JA, Tajara EH: Cytogenetic findings in two basal cell carcinomas. Cancer Genet Cytogenet 1994;73:152-156.

-3 Mertens F, Heim S, Mandahl N, Johansson B, Mertens O, Persson B, Salemark L, Wennerberg J, Jonsson N, Mitelman F: Cytogenetic analysis of 33 basal cell carcinomas. Cancer Res 1991;51:954-957.

-4 Ashton KJ, Weinstein SR, Maguire DJ, Griffiths LR: Molecular cytogenetic analysis of basal cell carcinoma DNA using comparative genomic hybridization. J Invest Dermatol 2001;117:683-686.
5 Saridaki Z, Koumantaki E, Liloglou T, Sourvinos G, Papadopoulos O, Zoras O, Spandidos DA: High frequency of loss of heterozygosity on chromosome region 9p21-p22 but lack of p16ink4a/p19arf mutations in Greek patients with basal cell carcinoma of the skin. J Invest Dermatol 2000;115:719-725.

6 Carless MA, Griffiths LR: Cytogenetics of melanoma and nonmelanoma skin cancer. Adv Exp Med Biol 2008;624:227-240.

7 Quinn AG, Sikkink S, Rees JL: Basal cell carcinomas and squamous cell carcinomas of human skin show distinct patterns of chromosome loss. Cancer Res 1994;54:4756-4759.

8 Shanley SM, Dawkins H, Wainwright BJ, Wicking C, Heenan P, Eldon M, Searle J, Chenevix-Trench G: Fine deletion mapping on the long arm of chromosome 9 in sporadic and familial basal cell carcinomas. Hum Mol Genet 1995;4:129-133.
Shen T, Park WS, Boni R, Saini N, Pham T, Lash AE, Vortmeyer AO, Zhuang Z: Detection of loss of heterozygosity on chromosome 9q22.3 in microdissected sporadic basal cell carcinoma. Hum Pathol 1999;30:284287.

10 Ramachandran S, Fryer AA, Lovatt T, Lear J, Smith AG, Strange RC: Susceptibility and modifier genes in cutaneous basal cell carcinomas and their associations with clinical phenotype. J Photochem Photobiol B 2001; 63:1-7.

11 Ramachandran S, Fryer AA, Smith A, Lear J, Bowers B, Jones PW, Strange RC: Cutaneous basal cell carcinomas: distinct host factors are associated with the development of tumors on the trunk and on the head and neck. Cancer 2001;92:354-358.

12 Wong CS, Strange RC, Lear JT: Basal cell carcinoma. BMJ 2003;327:794-798. 


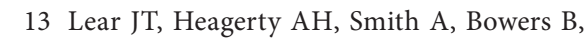
Payne CR, Smith CA, Jones PW, Gilford J, Yengi L, Alldersea J, Fryer AA, Strange RC: Multiple cutaneous basal cell carcinomas: flutathione S-transferase (GSTM1, GSTT1) and cytochrome P450 (CYP2D6, CYP1A1) polymorphisms influence tumour numbers and accrual. Carcinogenesis 1996;17:18911896.

14 Lear JT, Smith AG, Heagerty AH, Bowers B, Jones PW, Gilford J, Alldersea J, Strange RC, Fryer AA: Truncal site and detoxifying enzyme polymorphisms significantly reduce time to presentation of further primary cutaneous basal cell carcinoma. Carcinogenesis 1997; 18:1499-1503.

15 Yengi L, Inskip A, Gilford J, Alldersea J, Bailey L, Smith A, Lear JT, Heagerty AH, Bowers B, Hand P, Hayes JD, Jones PW, Strange RC, Fryer AA: Polymorphism at the glutathione S-transferase locus GSTM3: interactions with cytochrome P450 and glutathione Stransferase genotypes as risk factors for multiple cutaneous basal cell carcinoma. Cancer Res 1996;56:1974-1977.

16 Ramachandran S, Fryer AA, Smith AG, Lear JT, Bowers B, Hartland AJ, Whiteside JR, Jones PW, Strange RC: Basal cell carcinomas: association of allelic variants with a highrisk subgroup of patients with the multiple presentation phenotype. Pharmacogenetics 2001;11:247-254.

17 Ramachandran S, Hoban PR, Ichii-Jones F, Pleasants L, Ali-Osman F, Lear JT, Smith AG, Bowers B, Jones PW, Fryer AA, Strange RC: Glutathione S-transferase GSTP1 and cyclin D1 genotypes: association with numbers of basal cell carcinomas in a patient subgroup at high-risk of multiple tumours. Pharmacogenetics 2000;10:545-556.

- 18 Ramachandran S, Lear JT, Ramsay H, Smith AG, Bowers B, Hutchinson PE, Jones PW, Fryer AA, Strange RC: Presentation with multiple cutaneous basal cell carcinomas: association of glutathione S-transferase and cytochrome P450 genotypes with clinical phenotype. Cancer Epidemiol Biomarkers Prev 1999;8:61-67.

19 Gudbjartsson DF, Sulem P, Stacey SN, Goldstein AM, Rafnar T, Sigurgeirsson B, Benediktsdottir KR, Thorisdottir K, Ragnarsson R, Sveinsdottir SG, Magnusson V, Lindblom A, Kostulas K, Botella-Estrada R, Soriano V, Juberias P, Grasa M, Saez B, Andres R, Scherer D, Rudnai P, Gurzau E, Koppova K, Kiemeney LA, Jakobsdottir M, Steinberg S, Helgason A, Gretarsdottir S, Tucker MA, Mayordomo JI, Nagore E, Kumar R, Hansson J, Olafsson JH, Gulcher J, Kong A, Thorsteinsdottir U, Stefansson K: ASIP and TYR pigmentation variants associate with cutaneous melanoma and basal cell carcinoma. Nat Genet 2008;40:886-891.

-20 Stacey SN, Gudbjartsson DF, Sulem P, Bergthorsson JT, Kumar R, Thorleifsson G, Sigurdsson A, Jakobsdottir M, Sigurgeirsson B, Benediktsdottir KR, Thorisdottir K, Rag- narsson R, Scherer D, Rudnai P, Gurzau E, Koppova K, Hoiom V, Botella-Estrada R, Soriano V, Juberias $\mathrm{P}$, Grasa $\mathrm{M}$, Carapeto FJ, Tabuenca P, Gilaberte Y, Gudmundsson J, Thorlacius S, Helgason A, Thorlacius T, Jonasdottir A, Blondal T, Gudjonsson SA, Jonsson GF, Saemundsdottir J, Kristjansson K, Bjornsdottir G, Sveinsdottir SG, Mouy M, Geller F, Nagore E, Mayordomo JI, Hansson J, Rafnar T, Kong A, Olafsson JH, Thorsteinsdottir U, Stefansson K: Common variants on $1 \mathrm{p} 36$ and $1 \mathrm{q} 42$ are associated with cutaneous basal cell carcinoma but not with melanoma or pigmentation traits. Nat Genet 2008;40: 1313-1318.

-21 Gailani MR, Bale SJ, Leffell DJ, DiGiovanna JJ, Peck GL, Poliak S, Drum MA, Pastakia B, McBride OW, Kase R, et al: Developmental defects in Gorlin syndrome related to a putative tumor suppressor gene on chromosome 9. Cell 1992;69:111-117.

22 Hahn H, Wicking C, Zaphiropoulous PG, Gailani MR, Shanley S, Chidambaram A, Vorechovsky I, Holmberg E, Unden AB, Gillies S, Negus K, Smyth I, Pressman C, Leffell DJ, Gerrard B, Goldstein AM, Dean M, Toftgard R, Chenevix-Trench G, Wainwright B, Bale AE: Mutations of the human homolog of drosophila patched in the nevoid basal cell carcinoma syndrome. Cell 1996;85:841-851.

23 Johnson RL, Rothman AL, Xie J, Goodrich LV, Bare JW, Bonifas JM, Quinn AG, Myers RM, Cox DR, Epstein EH Jr, Scott MP: Human homolog of patched, a candidate gene for the basal cell nevus syndrome. Science 1996;272:1668-1671.

24 Klein RD, Dykas DJ, Bale AE: Clinical testing for the nevoid basal cell carcinoma syndrome in a DNA diagnostic laboratory. Genet Med 2005;7:611-619.

25 Gorlin RJ: Nevoid basal-cell carcinoma syndrome. Medicine (Baltimore) 1987;66:98113.

26 Adolphe C, Hetherington R, Ellis T, Wainwright B: Patched 1 functions as a gatekeeper by promoting cell cycle progression. Cancer Res 2006;66:2081-2088.

-27 Hutchin ME, Kariapper MS, Grachtchouk M, Wang A, Wei L, Cummings D, Liu J, Michael LE, Glick A, Dlugosz AA: Sustained hedgehog signaling is required for basal cell carcinoma proliferation and survival: conditional skin tumorigenesis recapitulates the hair growth cycle. Genes Dev 2005;19:214-223.

28 Bodak N, Queille S, Avril MF, Bouadjar B, Drougard C, Sarasin A, Daya-Grosjean L: High levels of patched gene mutations in basal-cell carcinomas from patients with xeroderma pigmentosum. Proc Natl Acad Sci USA 1999;96:5117-5122.

29 Couve-Privat S, Bouadjar B, Avril MF, Sarasin A, Daya-Grosjean L: Significantly high levels of ultraviolet-specific mutations in the smoothened gene in basal cell carcinomas from DNA repair-deficient xeroderma pigmentosum patients. Cancer Res 2002;62: 7186-7189.
30 Daya-Grosjean L, Sarasin A: UV-specific mutations of the human patched gene in basal cell carcinomas from normal individuals and xeroderma pigmentosum patients. $\mathrm{Mu}$ tat Res 2000;450:193-199.

-31 Aszterbaum M, Rothman A, Johnson RL, Fisher M, Xie J, Bonifas JM, Zhang X, Scott MP, Epstein EH Jr: Identification of mutations in the human patched gene in sporadic basal cell carcinomas and in patients with the basal cell nevus syndrome. J Invest Dermatol 1998;110:885-888.

32 Gailani MR, Stahle-Backdahl M, Leffell DJ, Glynn M, Zaphiropoulos PG, Pressman C, Unden AB, Dean M, Brash DE, Bale AE, Toftgard R: The role of the human homologue of Drosophila patched in sporadic basal cell carcinomas. Nat Genet 1996;14:78-81.

33 Reifenberger J, Wolter M, Weber RG, Megahed M, Ruzicka T, Lichter P, Reifenberger G: Missense mutations in $\mathrm{SMOH}$ in sporadic basal cell carcinomas of the skin and primitive neuroectodermal tumors of the central nervous system. Cancer Res 1998;58:17981803.

34 Xie J, Murone M, Luoh SM, Ryan A, Gu Q, Zhang C, Bonifas JM, Lam CW, Hynes M, Goddard A, Rosenthal A, Epstein EH Jr, de Sauvage FJ: Activating Smoothened mutations in sporadic basal-cell carcinoma. $\mathrm{Na}$ ture 1998;391:90-92.

35 Kinzler KW, Bigner SH, Bigner DD, Trent JM, Law ML, O’Brien SJ, Wong AJ, Vogelstein B: Identification of an amplified, highly expressed gene in a human glioma. Science 1987;236:70-73.

36 Pasca di Magliano M, Hebrok M: Hedgehog signalling in cancer formation and maintenance. Nat Rev Cancer 2003;3:903-911.

>37 Bonifas JM, Pennypacker S, Chuang PT, McMahon AP, Williams M, Rosenthal A, De Sauvage FJ, Epstein EH Jr: Activation of expression of hedgehog target genes in basal cell carcinomas. J Invest Dermatol 2001;116: 739-742.

38 Tojo M, Kiyosawa H, Iwatsuki K, Kaneko F: Expression of a sonic hedgehog signal transducer, hedgehog-interacting protein, by human basal cell carcinoma. Br J Dermatol 2002;146:69-73

-39 McMahon AP, Ingham PW, Tabin CJ: Developmental roles and clinical significance of hedgehog signaling. Curr Top Dev Biol 2003; 53:1-114.

40 Karhadkar SS, Bova GS, Abdallah N, Dhara S, Gardner D, Maitra A, Isaacs JT, Berman DM, Beachy PA: Hedgehog signalling in prostate regeneration, neoplasia and metastasis. Nature 2004;431:707-712.

41 Xie J: Molecular biology of basal and squamous cell carcinomas. Adv Exp Med Biol 2008;624:241-251.

42 Lee Y, Miller HL, Jensen P, Hernan R, Connelly $\mathrm{M}$, Wetmore $\mathrm{C}$, Zindy F, Roussel MF, Curran T, Gilbertson RJ, McKinnon PJ: A molecular fingerprint for medulloblastoma. Cancer Res 2003;63:5428-5437. 
-43 Thompson MC, Fuller C, Hogg TL, Dalton J, Finkelstein D, Lau CC, Chintagumpala M, Adesina A, Ashley DM, Kellie SJ, Taylor MD, Curran T, Gajjar A, Gilbertson RJ: Genomics identifies medulloblastoma subgroups that are enriched for specific genetic alterations. J Clin Oncol 2006;24:1924-1931.

-44 Bryden MM, Evans HE, Keeler RF: Cyclopia in sheep caused by plant teratogens. J Anat 1971;110:507.

45 Chen JK, Taipale J, Cooper MK, Beachy PA: Inhibition of Hedgehog signaling by direct binding of cyclopamine to Smoothened. Genes Dev 2002;16:2743-2748.

-46 Chen JK, Taipale J, Young KE, Maiti T, Beachy PA: Small molecule modulation of Smoothened activity. Proc Natl Acad Sci USA 2002;99:14071-14076.

-47 Frank-Kamenetsky M, Zhang XM, Bottega $\mathrm{S}$, Guicherit O, Wichterle H, Dudek H, Bumcrot D, Wang FY, Jones S, Shulok J, Rubin LL, Porter JA: Small-molecule modulators of Hedgehog signaling: identification and characterization of Smoothened agonists and antagonists. J Biol 2002;1:10.

-48 Tremblay MR, Nevalainen M, Nair SJ, Porter JR, Castro AC, Behnke ML, Yu LC, Hagel M, White K, Faia K, Grenier L, Campbell MJ, Cushing J, Woodward CN, Hoyt J, Foley MA, Read MA, Sydor JR, Tong JK, Palombella VJ, McGovern K, Adams J: Semisynthetic cyclopamine analogues as potent and orally bioavailable hedgehog pathway antagonists. J Med Chem 2008;51:6646-6649.

-49 Williams JA, Guicherit OM, Zaharian BI, Xu Y, Chai L, Wichterle H, Kon C, Gatchalian C, Porter JA, Rubin LL, Wang FY: Identification of a small molecule inhibitor of the hedgehog signaling pathway: effects on basal cell carcinoma-like lesions. Proc Natl Acad Sci USA 2003;100:4616-4621.

50 Molckovsky A, Siu LL: First-in-class, firstin-human phase I results of targeted agents: highlights of the 2008 American Society of Clinical Oncology meeting. J Hematol Oncol 2008;1:20.

-51 Tremblay MR, Lescarbeau A, Grogan MJ, Tan E, Lin G, Austad BC, Yu LC, Behnke ML, Nair SJ, Hagel M, White K, Conley J, Manna JD, Alvarez-Diez TM, Hoyt J, Woodward CN, Sydor JR, Pink M, Macdougall J, Campbell MJ, Cushing J, Ferguson J, Curtis MS, McGovern K, Read MA, Palombella VJ, Adams J, Castro AC: Discovery of a potent and orally active hedgehog pathway antagonist (ipi-926). J Med Chem 2009;52:4400-4418.

- 52 Romer JT, Kimura H, Magdaleno S, Sasai K, Fuller C, Baines H, Connelly M, Stewart CF, Gould S, Rubin LL, Curran T: Suppression of the Shh pathway using a small molecule inhibitor eliminates medulloblastoma in Ptc1(+/-)p53(-/-) mice. Cancer Cell 2004;6: 229-240.

-53 Sanchez P, Ruiz i Altaba A: In vivo inhibition of endogenous brain tumors through systemic interference of Hedgehog signaling in mice. Mech Dev 2005;122:223-230.
4 Von Hoff DD, LoRusso PM, Rudin CM, Reddy JC, Yauch RL, Tibes R, Weiss GJ, Borad MJ, Hann CL, Brahmer JR, Mackey HM, Lum BL, Darbonne WC, Marsters JC Jr, de Sauvage FJ, Low JA: Inhibition of the hedgehog pathway in advanced basal-cell carcinoma. N Engl J Med 2009;361:1164-1172.

55 Palma V, Lim DA, Dahmane N, Sanchez P, Brionne TC, Herzberg CD, Gitton Y, Carleton A, Alvarez-Buylla A, Ruiz i Altaba A: Sonic hedgehog controls stem cell behavior in the postnatal and adult brain. Development 2005; 132:335-344.

56 Sanchez P, Hernandez AM, Stecca B, Kahler AJ, DeGueme AM, Barrett A, Beyna M, Datta MW, Datta S, Ruiz i Altaba A: Inhibition of prostate cancer proliferation by interference with SONIC HEDGEHOG-GLI1 signaling. Proc Natl Acad Sci USA 2004;101: 12561-12566.

57 Thayer SP, di Magliano MP, Heiser PW, Nielsen CM, Roberts DJ, Lauwers GY, Qi YP, Gysin S, Fernandez-del Castillo C, Yajnik V, Antoniu B, McMahon M, Warshaw AL, Hebrok M: Hedgehog is an early and late mediator of pancreatic cancer tumorigenesis. Nature 2003;425:851-856.

58 Watkins DN, Berman DM, Burkholder SG, Wang B, Beachy PA, Baylin SB: Hedgehog signalling within airway epithelial progenitors and in small-cell lung cancer. Nature 2003;422:313-317.

59 Tabs S, Avci O: Induction of the differentiation and apoptosis of tumor cells in vivo with efficiency and selectivity. Eur J Dermatol 2004; 14:96-102.

60 Kuchler S, Herrmann W, Panek-Minkin G, Blaschke T, Zoschke C, Kramer KD, Bittl R, Schafer-Korting M: SLN for topical application in skin diseases - characterization of drug-carrier and carrier-target interactions. Int J Pharm 2010;390:225-233.

61 Kuchler S, Radowski MR, Blaschke T, Dathe M, Plendl J, Haag R, Schafer-Korting M, Kramer KD: Nanoparticles for skin penetration enhancement - a comparison of a dendritic core-multishell-nanotransporter and solid lipid nanoparticles. Eur J Pharm Biopharm 2009;71:243-250.

62 Schafer-Korting M, Holtje M, Korting HC, Holtje HD: Innovative agents for actinic keratosis and nanocarriers enhancing skin penetration. Skin Pharmacol Physiol 2010;23: 6-14.

63 Scales SJ, de Sauvage FJ: Mechanisms of hedgehog pathway activation in cancer and implications for therapy. Trends Pharmacol Sci 2009;30:303-312.

64 Dahmane N, Lee J, Robins P, Heller P, Ruiz i Altaba A: Activation of the transcription factor Glil and the Sonic hedgehog signalling pathway in skin tumours. Nature 1997;389: 876-881.

65 Rubin LL, de Sauvage FJ: Targeting the hedgehog pathway in cancer. Nature reviews 2006;5:1026-1033.
66 Unden AB, Zaphiropoulos PG, Bruce K, Toftgard R, Stahle-Backdahl M: Human patched $(\mathrm{PTCH})$ mRNA is overexpressed consistently in tumor cells of both familial and sporadic basal cell carcinoma. Cancer Res 1997;57:2336-2340.

-67 Rudin CM, Hann CL, Laterra J, Yauch RL, Callahan CA, Fu L, Holcomb T, Stinson J, Gould SE, Coleman B, LoRusso PM, Von Hoff DD, de Sauvage FJ, Low JA: Treatment of medulloblastoma with hedgehog pathway inhibitor GDC-0449. N Engl J Med 2009;361: 1173-1178.

68 Yauch RL, Dijkgraaf GJ, Alicke B, Januario T, Ahn CP, Holcomb T, Pujara K, Stinson J, Callahan CA, Tang T, Bazan JF, Kan Z, Seshagiri S, Hann CL, Gould SE, Low JA, Rudin $\mathrm{CM}$, de Sauvage FJ: Smoothened mutation confers resistance to a hedgehog pathway inhibitor in medulloblastoma. Science 2009; 326:572-574.

69 Hyman JM, Firestone AJ, Heine VM, Zhao Y, Ocasio CA, Han K, Sun M, Rack PG, Sinha S, Wu JJ, Solow-Cordero DE, Jiang J, Rowitch DH, Chen JK: Small-molecule inhibitors reveal multiple strategies for hedgehog pathway blockade. Proc Natl Acad Sci USA 2009; 106:14132-14137.

70 Stanton BZ, Peng LF: Small-molecule modulators of the Sonic Hedgehog signaling pathway. Mol Biosyst 2010;6:44-54.

-71 Wang Q, Huang S, Yang L, Zhao L, Yin Y, Liu Z, Chen Z, Zhang H: Down-regulation of Sonic hedgehog signaling pathway activity is involved in 5-fluorouracil-induced apoptosis and motility inhibition in Hep3B cells. Acta Biochim Biophys Sin (Shanghai) 2008; 40:819-829.

72 So PL, Lee K, Hebert J, Walker P, Lu Y, Hwang J, Kopelovich L, Athar M, Bickers D, Aszterbaum M, Epstein EH Jr: Topical tazarotene chemoprevention reduces basal cell carcinoma number and size in Ptch1+/mice exposed to ultraviolet or ionizing radiation. Cancer Res 2004;64:4385-4389.

73 So PL, Fujimoto MA, Epstein EH Jr: Pharmacologic retinoid signaling and physiologic retinoic acid receptor signaling inhibit basal cell carcinoma tumorigenesis. Mol Cancer Ther 2008;7:1275-1284.

74 Palamara F, Meindl S, Holcmann M, Luhrs P, Stingl G, Sibilia M: Identification and characterization of pDC-like cells in normal mouse skin and melanomas treated with imiquimod. J Immunol 2004;173:3051-3061.

75 Urosevic M, Dummer R: Immunotherapy for nonmelanoma skin cancer: does it have a future? Cancer 2002;94:477-485.

76 Urosevic M, Maier T, Benninghoff B, Slade H, Burg G, Dummer R: Mechanisms underlying imiquimod-induced regression of basal cell carcinoma in vivo. Arch Dermatol 2003;139:1325-1332.

77 Schon M, Schon MP: The antitumoral mode of action of imiquimod and other imidazoquinolines. Curr Med Chem 2007;14:681687. 
78 Schon MP, Schon M, Klotz KN: The small antitumoral immune response modifier imiquimod interacts with adenosine receptor signaling in a TLR7- and TLR8-independent fashion. J Invest Dermatol 2006;126:13381347.

79 Wuest M, Dummer R, Urosevic M: Induction of the members of Notch pathway in superficial basal cell carcinomas treated with imiquimod. Arch Dermatol Res 2007;299: 493-498.

-80 Trakatelli M, Ulrich C, del Marmol V, Euvrard S, Stockfleth E, Abeni D: Epidemiology of nonmelanoma skin cancer (NMSC) in Europe: accurate and comparable data are needed for effective public health monitoring and interventions. Br J Dermatol 2007; 156(suppl 3):1-7.

-81 Jalili A, Pinc A, Pieczkowski F, Karlhofer FM, Stingl G, Wagner SN: Combination of an EGFR blocker and a COX-2 inhibitor for the treatment of advanced cutaneous squamous cell carcinoma. J Dtsch Dermatol Ges 2008;6:1066-1069.

82 Kikuchi A, Amagai M, Hayakawa K, Ueda M, Hirohashi S, Shimizu N, Nishikawa T: Association of EGF receptor expression with proliferating cells and of ras p21 expression with differentiating cells in various skin tumours. Br J Dermatol 1990;123:49-58.

$\checkmark 83$ Lavrijsen AP, Tieben LM, Ponec M, van der Schroeff JG, van Muijen GN: Expression of EGF receptor, involucrin, and cytokeratins in basal cell carcinomas and squamous cell carcinomas of the skin. Arch Dermatol Res 1989;281:83-88.

-84 Shimizu T, Izumi H, Oga A, Furumoto H, Murakami T, Ofuji R, Muto M, Sasaki K: Epidermal growth factor receptor overexpression and genetic aberrations in metastatic squamous-cell carcinoma of the skin. Dermatology 2001;202:203-206.

-85 Fogarty GB, Conus NM, Chu J, McArthur G: Characterization of the expression and activation of the epidermal growth factor receptor in squamous cell carcinoma of the skin. Br J Dermatol 2007;156:92-98.

86 Baselga J: The EGFR as a target for anticancer therapy - focus on cetuximab. Eur J Cancer 2001;37(suppl 4):S16-S22.

87 Ciardiello F, Caputo R, Bianco R, Damiano V, Fontanini G, Cuccato S, De Placido S, Bianco AR, Tortora G: Inhibition of growth factor production and angiogenesis in human cancer cells by ZD1839 (Iressa), a selective epidermal growth factor receptor tyrosine kinase inhibitor. Clin Cancer Res 2001; 7:1459-1465.

88 Huang SM, Li J, Harari PM: Molecular inhibition of angiogenesis and metastatic potential in human squamous cell carcinomas after epidermal growth factor receptor blockade. Mol Cancer Ther 2002;1:507-514.
89 Maubec E, Petrow P, Duvillard P, Certain A, Duval X, Kerob D, Bagot M, Faivre S, Mentré F, Avril M: Cetuximab as first-line monotherapy in patients with unresectable squamous cell carcinoma of the skin: preliminary results of a phase II multicenter study (abstract). J Clin Oncol 2008;26(suppl):9042.

90 Engelman JA, Janne PA: Mechanisms of acquired resistance to epidermal growth factor receptor tyrosine kinase inhibitors in nonsmall cell lung cancer. Clin Cancer Res 2008; 14:2895-2899.

91 Johnson GL, Nakamura K: The c-jun kinase/ stress-activated pathway: Regulation, function and role in human disease. Biochim Biophys Acta 2007;1773:1341-1348.

92 Hu WG, Liu T, Xiong JX, Wang CY: Blockade of sonic hedgehog signal pathway enhances antiproliferative effect of EGFR inhibitor in pancreatic cancer cells. Acta Pharmacol Sin 2007;28:1224-1230.

93 Kasper M, Schnidar H, Neill GW, Hanneder M, Klingler S, Blaas L, Schmid C, HauserKronberger C, Regl G, Philpott MP, Aberger F: Selective modulation of hedgehog/gli target gene expression by epidermal growth factor signaling in human keratinocytes. Mol Cell Biol 2006;26:6283-6298.

94 Neill GW, Harrison WJ, Ikram MS, Williams TD, Bianchi LS, Nadendla SK, Green JL, Ghali L, Frischauf AM, O'Toole EA, Aberger F, Philpott MP: Glil repression of ERK activity correlates with colony formation and impaired migration in human epidermal keratinocytes. Carcinogenesis 2008;29: 738-746.

95 Schnidar H, Eberl M, Klingler S, Mangelberger D, Kasper M, Hauser-Kronberger C, Regl G, Kroismayr R, Moriggl R, Sibilia M, Aberger F: Epidermal growth factor receptor signaling synergizes with Hedgehog/GLI in oncogenic transformation via activation of the MEK/ERK/JUN pathway. Cancer Res 2009;69:1284-1292.

96 Laner-Plamberger S, Kaser A, Paulischta M, Hauser-Kronberger C, Eichberger T, Frischauf AM: Cooperation between GLI and JUN enhances transcription of JUN and selected GLI target genes. Oncogene 2009;28: 1639-1651.

97 Carter CA, Kelly RJ, Giaccone G: Small-molecule inhibitors of the human epidermal receptor family. Expert Opin Investig Drugs 2009;18:1829-1842.

-98 Janmaat ML, Gallegos-Ruiz MI, Rodriguez JA, Meijer GA, Vervenne WL, Richel DJ, Van Groeningen C, Giaccone G: Predictive factors for outcome in a phase II study of gefitinib in second-line treatment of advanced esophageal cancer patients. J Clin Oncol 2006;24:1612-1619.

99 Levi F, Te VC, Randimbison L, La Vecchia C: Trends in incidence of various morphologies of malignant melanoma in Vaud and Neuchatel, Switzerland. Melanoma Res 2005; 15 : 73-75.
100 Thomas RK, Baker AC, Debiasi RM, Winckler W, Laframboise T, Lin WM, Wang M, Feng W, Zander T, MacConaill L, Lee JC, Nicoletti R, Hatton C, Goyette M, Girard L, Majmudar K, Ziaugra L, Wong KK, Gabriel S, Beroukhim R, Peyton M, Barretina J, Dutt A, Emery C, Greulich H, Shah K, Sasaki H, Gazdar A, Minna J, Armstrong SA, Mellinghoff IK, Hodi FS, Dranoff G, Mischel PS, Cloughesy TF, Nelson SF, Liau LM, Mertz K, Rubin MA, Moch H, Loda M, Catalona W, Fletcher J, Signoretti S, Kaye F, Anderson KC, Demetri GD, Dummer R, Wagner S, Herlyn M, Sellers WR, Meyerson M, Garraway LA: Highthroughput oncogene mutation profiling in human cancer. Nat Genet 2007;39:347-351.

101 Tarhini AA, Agarwala SS: Cutaneous melanoma: Available therapy for metastatic disease. Dermatol Ther 2006;19:19-25.

102 Bastian BC, Kashani-Sabet M, Hamm H, Godfrey T, Moore DH 2nd, Brocker EB, LeBoit PE, Pinkel D: Gene amplifications characterize acral melanoma and permit the detection of occult tumor cells in the surrounding skin. Cancer Res 2000;60: 1968-1973.

103 Bastian BC, Olshen AB, LeBoit PE, Pinkel D: Classifying melanocytic tumors based on DNA copy number changes. Am J Pathol 2003; 163:1765-1770.

104 van Dijk M, Sprenger S, Rombout P, Marres H, Kaanders J, Jeuken J, Ruiter D: Distinct chromosomal aberrations in sinonasal mucosal melanoma as detected by comparative genomic hybridization. Genes Chromosomes Cancer 2003;36:151-158.

105 Curtin JA, Busam K, Pinkel D, Bastian BC: Somatic activation of KIT in distinct subtypes of melanoma. J Clin Oncol 2006;24: 4340-4346.

106 Curtin JA, Fridlyand J, Kageshita T, Patel HN, Busam KJ, Kutzner H, Cho KH, Aiba S, Brocker EB, LeBoit PE, Pinkel D, Bastian $\mathrm{BC}$ : Distinct sets of genetic alterations in melanoma. N Engl J Med 2005;353:21352147.

107 Viros A, Fridlyand J, Bauer J, Lasithiotakis K, Garbe C, Pinkel D, Bastian BC: Improving melanoma classification by integrating genetic and morphologic features. PLoS Med 2008;5:e120.

108 Markovic SN, Erickson LA, Rao RD, Weenig RH, Pockaj BA, Bardia A, Vachon CM, Schild SE, McWilliams RR, Hand JL, Laman SD, Kottschade LA, Maples WJ, Pittelkow MR, Pulido JS, Cameron JD, Creagan ET: Malignant melanoma in the 21st century. 1. Epidemiology, risk factors, screening, prevention, and diagnosis. Mayo Clin Proc 2007;82:364-380.

109 Patrick RJ, Fenske NA, Messina JL: Primary mucosal melanoma. J Am Acad Dermatol 2007;56:828-834. 
$\longrightarrow 110$ Smalley KS, Flaherty KT: Integrating braf/ mek inhibitors into combination therapy for melanoma. Br J Cancer 2009;100:431435.

-111 Dahl C, Guldberg P: The genome and epigenome of malignant melanoma. APMIS 2007;115:1161-1176.

112 Cohen C, Zavala-Pompa A, Sequeira JH, Shoji M, Sexton DG, Cotsonis G, Cerimele F, Govindarajan B, Macaron N, Arbiser JL: Mitogen-actived protein kinase activation is an early event in melanoma progression. Clin Cancer Res 2002;8:3728-3733.

- 113 Russo AE, Torrisi E, Bevelacqua Y, Perrotta R, Libra M, McCubrey JA, Spandidos DA, Stivala F, Malaponte G: Melanoma: Molecular pathogenesis and emerging target therapies (review). Int J Oncol 2009;34: 1481-1489.

- 114 Sharma A, Trivedi NR, Zimmerman MA, Tuveson DA, Smith CD, Robertson GP: Mutant V599EB-Raf regulates growth and vascular development of malignant melanoma tumors. Cancer Res 2005;65:2412-2421.

115 Bauer J, Curtin JA, Pinkel D, Bastian BC: Congenital melanocytic nevi frequently harbor NRAS mutations but no BRAF mutations. J Invest Dermatol 2007;127:179182.

116 Pollock PM, Harper UL, Hansen KS, Yudt LM, Stark M, Robbins CM, Moses TY, Hostetter G, Wagner U, Kakareka J, Salem G, Pohida T, Heenan P, Duray P, Kallioniemi O, Hayward NK, Trent JM, Meltzer PS: High frequency of BRAF mutations in nevi. Nat Genet 2003;33:19-20.

- 117 Yazdi AS, Palmedo G, Flaig MJ, Puchta U, Reckwerth A, Rutten A, Mentzel T, Hugel $\mathrm{H}$, Hantschke M, Schmid-Wendtner $\mathrm{MH}$, Kutzner H, Sander CA: Mutations of the BRAF gene in benign and malignant melanocytic lesions. J Invest Dermatol 2003;121: 1160-1162.

-118 Papp T, Pemsel H, Zimmermann R, Bastrop R, Weiss DG, Schiffmann D: Mutational analysis of the N-ras, p53, p16INK4a, $\mathrm{CDK} 4$, and MC1R genes in human congenital melanocytic naevi. J Med Genet 1999; 36:610-614

-119 Michaloglou C, Vredeveld LC, Soengas MS, Denoyelle C, Kuilman T, van der Horst CM, Majoor DM, Shay JW, Mooi WJ, Peeper DS: BRAFE600-associated senescence-like cell cycle arrest of human naevi. Nature 2005; 436:720-724.

120 Wilhelm SM, Carter C, Tang L, Wilkie D, McNabola A, Rong H, Chen C, Zhang X, Vincent P, McHugh M, Cao Y, Shujath J, Gawlak S, Eveleigh D, Rowley B, Liu L, Adnane L, Lynch M, Auclair D, Taylor I, Gedrich R, Voznesensky A, Riedl B, Post LE, Bollag G, Trail PA: BAY 43-9006 exhibits broad spectrum oral antitumor activity and targets the RAF/MEK/ERK pathway and receptor tyrosine kinases involved in tumor progression and angiogenesis. Cancer Res 2004;64:7099-7109.
121 Hauschild A, Agarwala SS, Trefzer U, Hogg D, Robert C, Hersey P, Eggermont A, Grabbe S, Gonzalez R, Gille J, Peschel C, Schadendorf D, Garbe C, O'Day S, Daud A, White JM, Xia C, Patel K, Kirkwood JM, Keilholz U: Results of a phase III, randomized, placebo-controlled study of sorafenib in combination with carboplatin and paclitaxel as second-line treatment in patients with unresectable stage III or stage IV melanoma. J Clin Oncol 2009;27:2823-2830.

122 King AJ, Patrick DR, Batorsky RS, Ho ML, Do HT, Zhang SY, Kumar R, Rusnak DW, Takle AK, Wilson DM, Hugger E, Wang L, Karreth F, Lougheed JC, Lee J, Chau D, Stout TJ, May EW, Rominger CM, Schaber MD, Luo L, Lakdawala AS, Adams JL, Contractor RG, Smalley KS, Herlyn M, Morrissey MM, Tuveson DA, Huang PS: Demonstration of a genetic therapeutic index for tumors expressing oncogenic BRAF by the kinase inhibitor SB-590885. Cancer Res 2006;66:11100-11105.

- 123 Fecher LA, Amaravadi R, Schuchter LM: Effectively targeting BRAF in melanoma: a formidable challenge. Pigment Cell Melanoma Res 2008;21:410-411.

124 Sala E, Mologni L, Truffa S, Gaetano C, Bollag GE, Gambacorti-Passerini C: BRAF silencing by short hairpin RNA or chemical blockade by PLX4032 leads to different responses in melanoma and thyroid carcinoma cells. Mol Cancer Res 2008;6:751-759.

125 Tsai J, Lee JT, Wang W, Zhang J, Cho H, Mamo S, Bremer R, Gillette S, Kong J, Haass NK, Sproesser K, Li L, Smalley KS, Fong D, Zhu YL, Marimuthu A, Nguyen H, Lam B, Liu J, Cheung I, Rice J, Suzuki Y, Luu C, Settachatgul C, Shellooe R, Cantwell J, Kim SH, Schlessinger J, Zhang KY, West BL, Powell B, Habets G, Zhang C, Ibrahim PN, Hirth P, Artis DR, Herlyn M, Bollag G: Discovery of a selective inhibitor of oncogenic B-Raf kinase with potent antimelanoma activity. Proc Natl Acad Sci USA 2008; 105:3041-3046.

126 Puzanov I, Nathanson KL, Chapman PB, $\mathrm{Xu}$ X, Sosman JA, McArthur GA, Ribas A, Kim KB, Grippo JF, Flaherty KT: PLX4032, a highly selective V600E BRAF kinase inhibitor: clinical correlation of activity with pharmacokinetic and pharmacodynamic parameters in a phase I trial (abstract). J Clin Oncol 2009;27:15s:9021.

127 Flaherty K, Puzanov I, Sosman J, Kim K, Ribas A, McArthur G, Lee RJ, Grippo JF, Nolop K, Chapman PB: Phase I study of PLX4032: proof of concept for V600E BRAF mutation as a therapeutic target in human cancer (abstract). J Clin Oncol 2009;27: $15 \mathrm{~s}: 9000$.

128 Montagut C, Settleman J: Targeting the RAF-MEK-ERK pathway in cancer therapy. Cancer Lett 2009;283:125-134.
129 Haass NK, Sproesser K, Nguyen TK, Contractor R, Medina CA, Nathanson KL, Herlyn M, Smalley KS: The mitogen-activated protein/extracellular signal-regulated kinase kinase inhibitor AZD6244 (ARRY-142886) induces growth arrest in melanoma cells and tumor regression when combined with docetaxel. Clin Cancer Res 2008;14:230-239.

130 Yeh TC, Marsh V, Bernat BA, Ballard J, Colwell H, Evans RJ, Parry J, Smith D, Brandhuber BJ, Gross S, Marlow A, Hurley B, Lyssikatos J, Lee PA, Winkler JD, Koch K, Wallace E: Biological characterization of ARRY-142886 (AZD6244), a potent, highly selective mitogen-activated protein kinase kinase 1/2 inhibitor. Clin Cancer Res 2007; 13:1576-1583.

131 Dummer R, Robert C, Chapman PB, Sosman JA, Middleton M, Bastholt L, Kemsley K, Cantarini MV, Morris C, Kirkwood JM: AZD6244 (ARRY-142886) vs. temozolomide (TMZ) in patients (PTS) with advanced melanoma: an open-label, randomized, multicenter, phase II study (abstract). J Clin Oncol 2008;26(suppl):9033.

132 Morgillo F, Lee HY: Lonafarnib in cancer therapy. Expert Opin Investig Drugs 2006; 15:709-719.

133 Eisen T, Ahmad T, Flaherty KT, Gore M, Kaye S, Marais R, Gibbens I, Hackett S, James M, Schuchter LM, Nathanson KL, Xia C, Simantov R, Schwartz B, PoulinCostello M, O'Dwyer PJ, Ratain MJ: Sorafenib in advanced melanoma: a phase II randomised discontinuation trial analysis. Br J Cancer 2006;95:581-586.

134 McDermott DF, Sosman JA, Gonzalez R, Hodi FS, Linette GP, Richards J, Jakub JW, Beeram M, Tarantolo S, Agarwala S, Frenette G, Puzanov I, Cranmer L, Lewis K, Kirkwood J, White JM, Xia C, Patel K, Hersh E: Double-blind randomized phase II study of the combination of sorafenib and dacarbazine in patients with advanced melanoma: a report from the 11715 study group. J Clin Oncol 2008;26:2178-2185.

135 Yarden Y, Kuang WJ, Yang-Feng T, Coussens L, Munemitsu S, Dull TJ, Chen E, Schlessinger J, Francke U, Ullrich A: Human proto-oncogene c-kit: a new cell surface receptor tyrosine kinase for an unidentified ligand. EMBO J 1987;6:3341-3351.

136 Yarden Y, Ullrich A: Molecular analysis of signal transduction by growth factors. Biochemistry 1988;27:3113-3119.

137 Yarden Y, Ullrich A: Growth factor receptor tyrosine kinases. Annu Rev Biochem 1988;57:443-478.

138 Vandenbark GR, deCastro CM, Taylor H, Dew-Knight S, Kaufman RE: Cloning and structural analysis of the human c-kit gene. Oncogene 1992;7:1259-1266.

139 Giebel LB, Strunk KM, Holmes SA, Spritz RA: Organization and nucleotide sequence of the human KIT (mast/stem cell growth factor receptor) proto-oncogene. Oncogene 1992;7:2207-2217. 
140 Wehrle-Haller B: The role of Kit-ligand in 151 Beadling C, Jacobson-Dunlop E, Hodi FS, melanocyte development and epidermal homeostasis. Pigment Cell Res 2003;16: 287-296.

141 Sattler M, Salgia R: Targeting c-Kit mutations: basic science to novel therapies. Leuk Res 2004;28(suppl 1):S11-S20.

142 Smolich BD, Yuen HA, West KA, Giles FJ, Albitar M, Cherrington JM: The antiangiogenic protein kinase inhibitors SU5416 and SU6668 inhibit the SCF receptor (c-kit) in a human myeloid leukemia cell line and in acute myeloid leukemia blasts. Blood 2001; 97:1413-1421.

143 Nishida T, Shirao K, Sawaki A, Koseki M, Okamura T, Ohtsu A, Sugiyama T, Miyakawa K, Hirota S: Efficacy and safety profile of imatinib mesylate (ST1571) in Japanese patients with advanced gastrointestinal stromal tumors: A phase ii study (STI571b1202). Int J Clin Oncol 2008;13: 244-251.

144 Hirota S, Isozaki K, Moriyama Y, Hashimoto K, Nishida T, Ishiguro S, Kawano K, Hanada M, Kurata A, Takeda M, Muhammad Tunio G, Matsuzawa Y, Kanakura Y, Shinomura Y, Kitamura Y: Gain-of-function mutations of c-kit in human gastrointestinal stromal tumors. Science 1998;279:577-580.

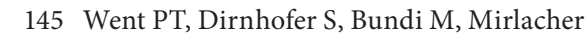
M, Schraml P, Mangialaio S, Dimitrijevic S, Kononen J, Lugli A, Simon R, Sauter G: Prevalence of KIT expression in human tumors. J Clin Oncol 2004;22:4514-4522.

$\checkmark 146$ Willmore-Payne C, Holden JA, Hirschowitz S, Layfield LJ: BRAF and c-kit gene copy number in mutation-positive malignant melanoma. Hum Pathol 2006;37:520-527.

$\checkmark 147$ Antonescu CR, Busam KJ, Francone TD, Wong GC, Guo T, Agaram NP, Besmer P, Jungbluth A, Gimbel M, Chen CT, Veach D, Clarkson BD, Paty PB, Weiser MR: L576P KIT mutation in anal melanomas correlates with kit protein expression and is sensitive to specific kinase inhibition. Int J Cancer 2007;121:257-264.

148 Jiang X, Zhou J, Yuen NK, Corless CL, Heinrich MC, Fletcher JA, Demetri GD, Widlund HR, Fisher DE, Hodi FS: Imatinib targeting of KIT-mutant oncoprotein in melanoma. Clin Cancer Res 2008;14:77267732 .

-149 Satzger I, Schaefer T, Kuettler U, Broecker V, Voelker B, Ostertag H, Kapp A, Gutzmer R: Analysis of c-KIT expression and KIT gene mutation in human mucosal melanomas. Br J Cancer 2008;99:2065-2069.

- 150 Ashida A, Takata M, Murata H, Kido K, Saida T: Pathological activation of KIT in metastatic tumors of acral and mucosal melanomas. Int J Cancer 2009;124:862868.
Le C, Warrick A, Patterson J, Town A, Harlow A, Cruz F 3rd, Azar S, Rubin BP, Muller S, West R, Heinrich MC, Corless CL: KIT gene mutations and copy number in melanoma subtypes. Clin Cancer Res 2008;14: 6821-6828.

152 Ugurel S, Hildenbrand R, Zimpfer A, La Rosee P, Paschka P, Sucker A, Keikavoussi P, Becker JC, Rittgen W, Hochhaus A, Schadendorf D: Lack of clinical efficacy of imatinib in metastatic melanoma. Br J Cancer 2005;92:1398-1405.

153 Kim KB, Eton O, Davis DW, Frazier ML, McConkey DJ, Diwan AH, Papadopoulos NE, Bedikian AY, Camacho LH, Ross MI, Cormier JN, Gershenwald JE, Lee JE, Mansfield PF, Billings LA, Ng CS, Charnsangavej C, Bar-Eli M, Johnson MM, Murgo AJ, Prieto VG: Phase II trial of imatinib mesylate in patients with metastatic melanoma. Br J Cancer 2008;99:734-740.

154 Wyman K, Atkins MB, Prieto V, Eton O, McDermott DF, Hubbard F, Byrnes C, Sanders K, Sosman JA: Multicenter phase II trial of high-dose imatinib mesylate in metastatic melanoma: significant toxicity with no clinical efficacy. Cancer 2006;106:20052011.

155 Hodi FS, Friedlander P, Corless CL, Heinrich MC, Mac Rae S, Kruse A, Jagannathan J, Van den Abbeele AD, Velazquez EF, Demetri GD, Fisher DE: Major response to imatinib mesylate in KIT-mutated melanoma. J Clin Oncol 2008;26:2046-2051.

156 Lutzky J, Bauer J, Bastian BC: Dose-dependent, complete response to imatinib of a metastatic mucosal melanoma with a K642E KIT mutation. Pigment Cell Melanoma Res 2008;21:492-493.

157 Buchdunger E, Cioffi CL, Law N, Stover D, Ohno-Jones S, Druker BJ, Lydon NB: Abl protein-tyrosine kinase inhibitor STI571 inhibits in vitro signal transduction mediated by c-kit and platelet-derived growth factor receptors. J Pharmacol Exp Ther 2000;295:139-145.

158 Heinrich MC, Griffith DJ, Druker BJ, Wait CL, Ott KA, Zigler AJ: Inhibition of c-kit receptor tyrosine kinase activity by STI 571, a selective tyrosine kinase inhibitor. Blood 2000;96:925-932.

159 Krystal GW, Honsawek S, Litz J, Buchdunger E: The selective tyrosine kinase inhibitor STI571 inhibits small cell lung cancer growth. Clin Cancer Res 2000;6:33193326.

160 Wang WL, Healy ME, Sattler M, Verma S, Lin J, Maulik G, Stiles CD, Griffin JD, Johnson BE, Salgia R: Growth inhibition and modulation of kinase pathways of small cell lung cancer cell lines by the novel tyrosine kinase inhibitor STI 571. Oncogene 2000; 19:3521-3528.
61 Okuda K, Weisberg E, Gilliland DG, Griffin JD: ARG tyrosine kinase activity is inhibited by STI571. Blood 2001;97:24402448.

162 Savage P, Jeng AY: Upregulation of endothelin-1 binding in tissues of salt-loaded stroke-prone spontaneously hypertensive rats. Can J Physiol Pharmacol 2002;80:470474.

163 McLean SR, Gana-Weisz M, Hartzoulakis B, Frow R, Whelan J, Selwood D, Boshoff C: Imatinib binding and cKIT inhibition is abrogated by the cKIT kinase domain I missense mutation Val654Ala. Mol Cancer Ther 2005;4:2008-2015.

164 Heinrich MC, Joensuu H, Demetri GD, Corless CL, Apperley J, Fletcher JA, Soulieres D, Dirnhofer S, Harlow A, Town A, McKinley A, Supple SG, Seymour J, Di Scala L, van Oosterom A, Herrmann R, Nikolova Z, McArthur AG: Phase II, open-label study evaluating the activity of imatinib in treating life-threatening malignancies known to be associated with imatinib-sensitive tyrosine kinases. Clin Cancer Res 2008; 14:2717-2725.

165 Gloster HM Jr: Dermatofibrosarcoma protuberans. J Am Acad Dermatol 1996;35: 355-374; quiz 375-376.

166 Criscione VD, Weinstock MA: Descriptive epidemiology of dermatofibrosarcoma protuberans in the United States, 1973 to 2002. J Am Acad Dermatol 2007;56:968-973.

167 Bednar B: Storiform neurofibromas of the skin, pigmented and nonpigmented. Cancer 1957;10:368-376.

168 Simon MP, Pedeutour F, Sirvent N, Grosgeorge J, Minoletti F, Coindre JM, TerrierLacombe MJ, Mandahl N, Craver RD, Blin N, Sozzi G, Turc-Carel C, O’Brien KP, Kedra D, Fransson I, Guilbaud C, Dumanski JP: Deregulation of the platelet-derived growth factor B-chain gene via fusion with collagen gene COL1 A 1 in dermatofibrosarcoma protuberans and giant-cell fibroblastoma. Nat Genet 1997;15:95-98.

169 Diwan AH, Skelton HG 3rd, Horenstein MG, Kelly DR, Barrett TL, Bussian AH, Sanders DY, Lazar AJ, Prieto VG, Smith KJ: Dermatofibrosarcoma protuberans and giant cell fibroblastoma exhibit CD99 positivity. J Cutan Pathol 2008;35:647-650.

170 Lemm D, Mugge LO, Mentzel T, Hoffken K: Current treatment options in dermatofibrosarcoma protuberans. J Cancer Res Clin Oncol 2009;135:653-665.

-171 Mendenhall WM, Zlotecki RA, Scarborough MT: Dermatofibrosarcoma protuberans. Cancer 2004;101:2503-2508.

172 Thornton SL, Reid J, Papay FA, Vidimos AT: Childhood dermatofibrosarcoma protuberans: role of preoperative imaging. J Am Acad Dermatol 2005;53:76-83. 
173 Ugurel S, Kortmann RD, Mohr P, Mentzel T, Garbe C, Breuninger H: Short German guidelines: dermatofibrosarcoma protuberans. J Dtsch Dermatol Ges 2008;6(suppl 1):S17-S18.

174 Bowne WB, Antonescu CR, Leung DH, Katz SC, Hawkins WG, Woodruff JM, Brennan MF, Lewis JJ: Dermatofibrosarcoma protuberans: a clinicopathologic analysis of patients treated and followed at a single institution. Cancer 2000;88:2711-2720.

175 Parker TL, Zitelli JA: Surgical margins for excision of dermatofibrosarcoma protuberans. J Am Acad Dermatol 1995;32:233-236.

176 Gloster HM Jr, Harris KR, Roenigk RK: A comparison between Mohs micrographic surgery and wide surgical excision for the treatment of dermatofibrosarcoma protuberans. J Am Acad Dermatol 1996;35:8287.

177 Suit H, Spiro I, Mankin HJ, Efird J, Rosenberg AE: Radiation in management of patients with dermatofibrosarcoma protuberans. J Clin Oncol 1996;14:2365-2369.

178 Ballo MT, Zagars GK, Pisters P, Pollack A The role of radiation therapy in the management of dermatofibrosarcoma protuberans. Int J Radiat Oncol Biol Phys 1998; 40:823-827.

179 Sun LM, Wang CJ, Huang CC, Leung SW, Chen HC, Fang FM, Huang EY, Lee SP: Dermatofibrosarcoma protuberans: treatment results of 35 cases. Radiother Oncol 2000;57:175-181.
180 Dagan R, Morris CG, Zlotecki RA, Scarborough MT, Mendenhall WM: Radiotherapy in the treatment of dermatofibrosarcoma protuberans. Am J Clin Oncol 2005;28: 537-539.

181 McArthur GA: Dermatofibrosarcoma protuberans: a surgical disease with a molecular savior. Curr Opin Oncol 2006;18:341346.

182 Sandberg AA, Bridge JA: Updates on the cytogenetics and molecular genetics of bone and soft tissue tumors: dermatofibrosarcoma protuberans and giant cell fibroblastoma. Cancer Genet Cytogenet 2003; 140:1-12.

183 Shimizu A, O’Brien KP, Sjoblom T, Pietras $\mathrm{K}$, Buchdunger E, Collins VP, Heldin $\mathrm{CH}$, Dumanski JP, Ostman A: The dermatofibrosarcoma protuberans-associated collagen type Ialpha1/platelet-derived growth factor (PDGF) B-chain fusion gene generates a transforming protein that is processed to functional PDGF-BB. Cancer Res 1999;59:3719-3723.

184 Fish FS: Soft tissue sarcomas in dermatology. Dermatol Surg 1996;22:268-273.

185 Sjöblom T, Shimizu A, O’Brien KP, Pietras K, Dal Cin P, Buchdunger E, Dumanski JP, Ostman A, Heldin CH: Growth inhibition of dermatofibrosarcoma protuberans tumors by the platelet-derived growth factor receptor antagonist STI571 through induction of apoptosis. Cancer Res 2001;61:57785783.
86 McArthur GA, Demetri GD, van Oosterom A, Heinrich MC, Debiec-Rychter M, Corless CL, Nikolova Z, Dimitrijevic S, Fletcher JA: Molecular and clinical analysis of locally advanced dermatofibrosarcoma protuberans treated with imatinib: Imatinib Target Exploration Consortium Study B2225. J Clin Oncol 2005;23:866-873.

187 Rubin BP, Schuetze SM, Eary JF, Norwood TH, Mirza S, Conrad EU, Bruckner JD: Molecular targeting of platelet-derived growth factor B by imatinib mesylate in a patient with metastatic dermatofibrosarcoma protuberans. J Clin Oncol 2002;20:3586-3591.

188 Price VE, Fletcher JA, Zielenska M, Cole W, Viero S, Manson DE, Stuart M, Pappo AS Imatinib mesylate: an attractive alternative in young children with large, surgically challenging dermatofibrosarcoma protuberans. Pediatr Blood Cancer 2005;44:511515.

189 Labropoulos SV, Fletcher JA, Oliveira AM, Papadopoulos S, Razis ED: Sustained complete remission of metastatic dermatofibrosarcoma protuberans with imatinib mesylate. Anticancer Drugs 2005;16:461-466.

190 Han A, Chen EH, Niedt G, Sherman W, Ratner D: Neoadjuvant imatinib therapy for dermatofibrosarcoma protuberans. Arch Dermatol 2009;145:792-796. 